\title{
Problems associated with indwelling central venous catheters
}

\author{
P J DARBYSHIRE, N C WEIGHTMAN, AND D C E SPELLER
}

Department of Paediatric Haematology/Oncology, Bristol Children's Hospital and Department of Microbiology, Bristol Royal Infirmary

SUMMARY Forty nine Broviac or Hickman indwelling central venous catheters were inserted in 36 patients with haematological and neoplastic diseases for indications including young age, intensity of treatment, and psychological attitude. Sixteen patients suffered 29 episodes of infection related to the catheter bacteraemia ( 0.68 episodes per 100 days of catheter use). Infections occurred much more commonly where there was intensive use of the catheter than with relatively light catheter use. Twenty episodes were caused by a single bacterial strain and nine by multiple strains; coagulase negative staphylococci accounted for $51 \%$ of the strains isolated. Altogether $72 \%$ of infections were cured by antibiotic treatment, which was more likely to be successful in eradicating single than multiple infections. Although infection was common, mechanical problems were a more usual reason for catheter removal. There were no deaths caused by catheter related infection.

Since the introduction by Broviac et al $^{1}$ in 1973 and Hickman $e t a l^{2}$ in 1974 of the indwelling catheters which now bear their names, the use of implanted central venous catheters has become widespread. There is no doubting their convenience both to the physician and to the patient for quick, easy venous access for any purpose. They are of particular value if the patient is an infant or young child who requires intensive chemotherapy for malignant disease. Infective complications constitute the most serious risk in the immunosuppressed patient and several workers $^{3-5}$ have documented a higher incidence of infection by coagulase negative staphylococci ('Staphylococcus albus') after use of these catheters.

We analyse our first three years of experience with these catheters in the haematology/oncology unit at Bristol Children's Hospital. In particular, episodes of catheter related bacteraemia (often with multiple bacterial strains) are presented and risk factors, prognosis, and management are discussed.

\section{Patients and methods}

Patients, catheter insertion and care. Hickman and Broviac catheters have been in regular use in this unit since 1981. They have all been inserted under general anaesthetic by one surgeon. All were placed in the superior vena cava or right atrium-usually via the external jugular vein; rarely via the cephalic or internal jugular veins. All were tunnelled to an exit site on the anterior chest wall medial to the nipple. The type of catheter inserted depended mainly on the size of the child; Broviac catheters were used in infants and young children, and the larger Hickman catheters in older children.

Three groups of patients were selected as most likely to benefit from central venous access of this type. These were:

(a) Children under 2 years of age who required chemotherapy.

(b) Children over 2 years of age who were to receive very intensive chemotherapy.

(c) Children who were experiencing particular psychological difficulties with injections and chemotherapy.

Primary induction therapy of acute lymphoblastic leukaemia was not in itself regarded as an indication for catheter placement at any age.

After consultation with the patient and parents, most catheters were inserted early in the course of treatment, usually within the first week. All catheters received similar care from a small group of nurses. After the initial postoperative period a new non-occlusive dressing was applied to the insertion site each week; no antibiotic preparations were applied. In both inpatients and outpatients the 
catheter, when not in use, was flushed twice daily with $5 \mathrm{ml}$ of heparin solution $(10 \mathrm{U} / \mathrm{ml}$ Hepsal, Weddel). Any procedure involving use of the catheter was performed with sterile precautions, and the catheter was flushed with the heparin solution after use of any kind. Before the patient was discharged from hospital, one parent had to satisfy the nursing team of his or her competence in care of the catheter.

As patients received all treatment through the catheter-blood sampling, chemotherapy, intravenous fluids, blood products, and intravenous feeding - the catheters often received heavy use, particularly in the early weeks of treatment. The children were usually nursed on an open ward and prophylactic antibiotics were not given. An attempt has been made to stratify the relation between catheter use and infection as follows:

Type 1: outpatient care in the week preceding bacteraemia.

Type 2: mainly inpatient care in the week before bacteraemia.

Type 3: entirely inpatient care in the week preceding bacteraemia, with use of the catheter for daily blood products or intravenous feeding.

Investigation of febrile episodes. All infections in patients with indwelling catheters were carefully documented. After confirmation of a temperature of $38.0^{\circ} \mathrm{C}$ or above, full bacterial and viral screening was performed. Blood for culture was drawn from the catheter and from a peripheral vein. If the patient was neutropenic (less than $1 \times 10^{9}$ neutrophils/l). empirical antibiotic treatment was begun (either cefuroxime or ceftazidime in combination with tobramycin). In the absence of neutropenia, the preferred strategy was to wait for culture results before choosing the most appropriate antimicrobial drug.

Microbiological methods. For blood culture, $5 \mathrm{ml}$ or less of blood was added to each of two media: $40 \mathrm{ml}$ of brain heart infusion broth with $0.05 \%$ sodium polyanethol sulphonate and $10 \%$ sucrose, and $80 \mathrm{ml}$ brain heart infusion broth with $0 \cdot 8 \%$ sodium thioglycollate. If fungal infection was suspected an additional diphasic medium was inoculated. The media were subcultured at one day and seven days and when there was macroscopic evidence of bacterial growth. Quantitative blood culture was not performed. Bacterial isolates were identified by routine laboratory methods and by appropriate API identification kits (API System, France). All isolates were tested for sensitivity to a wide range of relevant antibacterial agents by a controlled disc diffusion method. Different strains of the same species were detected and differentiated by colonial characteristics, biological reactions, and antibiotic sensitivity. Selected isolates were submitted for serotyping.

Definitions. Patients were considered to have related to the catheter bacteraemia when one or more of the blood cultures were positive (two or more in the case of coagulase negative staphylococci) and no other site of infection was identified.

Cure of a catheter related infection was confirmed by clinical improvement, abatement of fever, and a negative blood culture drawn from the catheter 24 hours or more after antibiotics had been stopped.

Bacterial isolates of the same species were considered to be different strains if they differed in serotype, or in two or more unrelated biochemical characters, or in two or more antibiotic sensitivities (of antibiotics in different functional groups).

Failure to eradicate an infection was defined as either removal of the catheter because the infection had not been controlled by antibiotics or recurrence of bacteraemia with one or more of the same bacterial strains after a course of appropriate antibiotic treatment had been given.

\section{Results}

A total of 49 indwelling central venous catheters (24 Broviac and 25 Hickman catheters) have now been placed in 36 children. Thirteen children had catheters inserted primarily because of young age, 19 because of the planned intensity of chemotherapy, and four for psychological reasons. The 36 children were being treated for a range of conditions; acute leukaemia at presentation or relapse, ${ }^{9}$ non-Hodgkin's lymphoma ${ }^{8}$ solid tumours of various histological types, ${ }^{18}$, and aplastic anaemia. ${ }^{1}$ Problems at insertion were rare; only one child, who developed disseminated intravascular coagulation, had severe bleeding. The ages of the patients ranged from 5 weeks to 17 years with a median of 2 years and a mean of 6 years. A total of 143 patient months of catheter use has now accrued, each catheter having an average life of 2.93 months, ranging from 24 hours (to include early technical failures) to 11 months, with a median of 11 weeks.

Infection has been the most serious problem and a total of 29 bacterial infections related to catheter use have been identified in 16 patients; 20 remained free of infection. In the total group of 36 patients, a further three bacteraemias occurred in which an alternative primary site for the infection was found; in only one patient was this site the external tunnel of the catheter. Table 1 details the patients and episodes of catheter related bacteraemia, the microbial isolates, treatment, and outcome; and Table 2 
Table 1 Episodes of catheter related infection, micro-organisms isolated, treatment, and outcome

\begin{tabular}{|c|c|c|c|c|c|c|}
\hline \multicolumn{2}{|c|}{$\begin{array}{l}\text { Patient } \\
\text { (No of episodes) }\end{array}$} & \multirow{2}{*}{$\begin{array}{l}\text { Organism(s) } \\
\text { Candida glabrata }\end{array}$} & \multirow{2}{*}{$\begin{array}{l}\text { Type of } \\
\text { catheter }\end{array}$} & \multirow{2}{*}{$\begin{array}{l}\begin{array}{l}\text { Neutropenic } \\
\left(<1 \times 10^{9} i 1\right)\end{array} \\
\text { No }\end{array}$} & \multirow{2}{*}{$\begin{array}{l}\text { Treatment } \\
\text { Not attempted }\end{array}$} & \multirow{2}{*}{$\begin{array}{l}\text { Outcome } \\
\text { Catheter removed, no treatment } \\
\text { attempted }\end{array}$} \\
\hline & (1) & & & & & \\
\hline & (1) & Staphylococcus hominis & B & No & Flucloxacillin & Cure \\
\hline \multirow[t]{3}{*}{2\{} & (2) & $\begin{array}{l}\text { Coagulase negative } \\
\text { staphylococcus* }\end{array}$ & B & No & Netilmicin & $\begin{array}{l}\text { Failure; catheter removed because of } \\
\text { infection }\end{array}$ \\
\hline & (3) & $\begin{array}{l}\text { Staph epidermidis ( } 2 \text { strains) }+ \\
\text { Staph haemolyticus }\end{array}$ & B & No & $\begin{array}{l}\text { Rifampicin, } \\
\text { netilmicin }\end{array}$ & $\begin{array}{l}\text { Failure; catheter removed because of } \\
\text { infection }\end{array}$ \\
\hline & (4) & Staph epidermidis $\dagger$ (2 strains) & B & No & Trimethoprim & Cure \\
\hline \multirow{2}{*}{3} & (1) & Staph warneri & $\mathrm{H}$ & No & Cefuroxime & Catheter removed because of fracture \\
\hline & (1) & Staph epidermidis (4 strains) & B & No & Vancomycin & $\begin{array}{l}\text { Failure; recurrence of one strain after } \\
\text { treatment }\end{array}$ \\
\hline \multirow[t]{2}{*}{4} & (2) & Staph epidermidis & B & No & Vancomycin & $\begin{array}{l}\text { Failure; recurrence of one strain after } \\
\text { treatment }\end{array}$ \\
\hline & (3) & $\begin{array}{l}\text { Staph epidermidis }+ \text { Acinetobacter } \\
\text { calcoaceticus var anitratus }\end{array}$ & B & No & Cefuroxime & $\begin{array}{l}\text { Failure; catheter removed because of } \\
\text { infection }\end{array}$ \\
\hline 5 & (1) & Staph saprophyticus & $\mathrm{H}$ & No & $\begin{array}{l}\text { Cefuroxime, } \\
\text { flucloxacillin }\end{array}$ & Cure \\
\hline \multirow[t]{4}{*}{6} & (1) & $\begin{array}{l}\text { Coagulase negative } \\
\text { staphylococcus* }\end{array}$ & $\mathbf{H}$ & Yes & $\begin{array}{l}\text { Vancomycin, } \\
\text { netilmicin }\end{array}$ & Cure \\
\hline & (2) & $\begin{array}{l}\text { Coagulase negative } \\
\text { staphylococcus } \dagger\end{array}$ & $\mathbf{H}$ & Yes & $\begin{array}{l}\text { Cefuroxime, } \\
\text { flucloxacillin }\end{array}$ & Cure \\
\hline & (3) & $\begin{array}{l}\text { Streptococcus mitior }+ \\
\quad \text { Escherichia coli }(3 \text { strains })\end{array}$ & $\mathbf{H}$ & Yes & $\begin{array}{l}\text { Erythromycin, } \\
\text { ampicillin, } \\
\text { gentamicin }\end{array}$ & $\begin{array}{l}\text { Failure; recurrence of two strains after } \\
\text { treatment }\end{array}$ \\
\hline & (4) & $\begin{array}{l}\text { Strep faecium }+ \\
\text { A calcoaceticus var anitratus }+ \\
\text { Esch coli }(4 \text { strains })\end{array}$ & $\mathbf{H}$ & Yes & $\begin{array}{l}\text { Ceftazidime, } \\
\text { ampicillin, } \\
\text { gentamicin }\end{array}$ & $\begin{array}{l}\text { Failure; catheter removed because of } \\
\text { infection }\end{array}$ \\
\hline 7 & (1) & Staph aureus & B & No & Flucloxacillin & Cure \\
\hline \multirow[t]{2}{*}{8} & (1) & Staph epidermidis & $\mathrm{H}$ & Yes & Vancomycin & Cure \\
\hline & (2) & Staph epidermidis $\uparrow$ & $\mathrm{H}$ & Yes & Vancomycin & Cure \\
\hline 9 & (1) & Enterobacter cloacae & $\mathrm{H}$ & Yes & $\begin{array}{l}\text { Cefuroximine, } \\
\text { gentamicin }\end{array}$ & Cure \\
\hline & (1) & Staph epidermidis & $\mathbf{H}$ & Yes & Cefuroxime & Cure \\
\hline & (1) & Staph epidermidis & B & No & $\begin{array}{l}\text { Flucloxacillin, } \\
\text { gentamicin }\end{array}$ & $\begin{array}{l}\text { Catheter removed before results of treatmen } \\
\text { assessed }\end{array}$ \\
\hline & (1) & Ent cloacae & B & Yes & Ampicillin & Cure \\
\hline & (1) & Strep sanguis & $\mathrm{H}$ & Yes & Penicillin & Cure \\
\hline & (1) & Staph aureus & B & Yes & Flucioxacillin & Cure \\
\hline & (2) & $\begin{array}{l}\text { Strep faecalis }+ \\
\quad \text { Ent agglomerans }\end{array}$ & B & Yes & $\begin{array}{l}\text { Ceftazidime, } \\
\text { tobramycin }\end{array}$ & $\begin{array}{l}\text { Catheter removed before results of treatmen } \\
\text { assessed }\end{array}$ \\
\hline & (1) & Klebsiella oxytoca & B & Yes & $\begin{array}{l}\text { Ceftazidime, } \\
\text { tobramycin }\end{array}$ & Cure \\
\hline & (2) & $\begin{array}{l}\text { Staph haemolyticus + } \\
\text { Staph hominis }\end{array}$ & B & Yes & Netilmicin & Cure \\
\hline \multirow{2}{*}{15} & (3) & Klebs oxytoca ${ }^{\dagger}$ & B & Yes & Ceftazidime & Cure \\
\hline & (4) & $\begin{array}{l}\text { Staph haemolyticus } \dagger+ \\
A \text { calcoaceticus var anitratus }\end{array}$ & B & Yes & $\begin{array}{r}\text { Vancomycin, } \\
\text { gentamicin }\end{array}$ & Cure \\
\hline & (1) & Strep pyogenes & B & Yes & Penicillin & Cure \\
\hline
\end{tabular}

${ }^{*}$ Not speciated; †different strain(s) from previous episode(s) in this patient. $\mathrm{H}=$ Hickman catheter; $\mathrm{B}=$ Broviac catheter.

summarises the organisms recovered. Twenty of the 29 episodes $(69 \%)$ were caused by a single microbial strain. Five of the nine episodes where there were multiple isolates yielded two strains; one, three strains; two, four strains; and one, six strains. Coagulase negative staphylococci accounted for 17 episodes of bacteraemia, either as a single isolate or in combination. Patients with this type of infection usually had a low grade fever (rarely above $38.5^{\circ} \mathrm{C}$ ) as the only sign, often remaining clinically well. No child infected by this bacterium became shocked, even in the presence of neutropenia. Ten of 12 $(83 \%)$ infections with bacteria other than coagulase negative staphylococci were in neutropenic patients, while 7 of $17(41 \%)$ infections with coagulase negative staphylococci were in neutropenic patients. Rigors related to flushing of the catheter were seen in four patients, two with coagulase negative staphylococcal infection, one with Klebsiella oxytoca, and one with Enterobacter cloacae.

An attempt to eradicate the infection with antibiotics was made on 28 occasions. Results of treatment could be assessed on 25 occasions, and were deemed successful in $18(72 \%)$. The line was removed for reasons other than failure to eradicate infection before treatment could be assessed on three occasions; and on one occasion no attempt at treatment was made (Candida glabrata). The pres- 
Table 2 Micro-organisms isolated in 29 episodes of catheter related bacteraemia

\begin{tabular}{|c|c|c|}
\hline Micro-organism & & No of strains isolated \\
\hline Coagulase negative staphylococci & & 22 \\
\hline Staphylococcus epidermidis & 12 & \\
\hline Staph haemolyticus & 3 & \\
\hline Staph hominis & 2 & \\
\hline Staph warneri & 1 & \\
\hline Staph saprophyticus & 1 & \\
\hline Not speciated & 3 & \\
\hline Staph aureus & & 2 \\
\hline Streptococcus pyogenes & & 1 \\
\hline Strep faecalis & & 1 \\
\hline Strep faecium & & 1 \\
\hline Strep mitior & & 1 \\
\hline Strep sanguis & & 1 \\
\hline Escherichia coli & & $\begin{array}{l}1 \\
5\end{array}$ \\
\hline Klebsiella oxytoca & & 2 \\
\hline Enterobacter cloacae & & 2 \\
\hline Ent agglomerans & & 1 \\
\hline Acinetobacter calcoaceticus var anitratus & & 3 \\
\hline Candida glabrata & & 1 \\
\hline Total & & 43 \\
\hline
\end{tabular}

ence of neutropenia did not seem to influence the likelihood of eradication of the infection. Among the episodes of infection that could be adequately assessed, those with multiple strains were cured on 3 of $8(38 \%)$ occasions, and those with a single strain on 15 of $17(88 \%)$ occasions. The difference was statistically highly significant $(P \leqslant 0 \cdot 01$; hypergeometric distribution exact test).

The use of the catheters was assessed by the criteria defined in the Methods section. In the week preceding the 29 catheter related bacteraemias, the catheter had been subjected to type 3 use in 17 cases, whereas most catheter use was of types 1 and 2. There was an overall incidence of 0.68 episodes of catheter related bacteraemia per 100 days of catheter use, and $44 \%$ of patients had one or more episodes of bacteraemia related to the catheter.

The reasons for removal of the catheters are given in Table 3. Over $20 \%$ of catheters were removed because of malposition, breakage, thrombosis, and even on two occasions accidental removal by the patients, while only four catheters were removed because of failure to eradicate infection, a further two being removed before the results of antimicrobial treatment were assessable. No serious incidents occurred among outpatients with indwelling catheters. In general the care given to the catheters by the patients and parents at home was good. No child with an indwelling central venous catheter in situ died of infection but four deaths have occurred in the patients described, all due to progressive disease.

All four children in whom the catheter was placed
Table 3 Reason for removal of indwelling central venous catheters

\begin{tabular}{lc}
\hline Reason for removal & $\begin{array}{l}\text { No of } \\
\text { Patients }\end{array}$ \\
\hline Elective removal & 11 \\
Died with line in situ & 4 \\
Malposition & 3 \\
High breaks & $4^{*}$ \\
Thrombosis & 1 \\
Accidental & 2 \\
Removed because of infection (failure of treatment) & 4 \\
Removed because of infection (without attempt at & \\
$\quad$ treatment) & 1 \\
Removed before results of treatment for infection & 2 \\
$\quad$ assessable & 17 \\
Still in situ & 49 \\
Total &
\end{tabular}

*Includes one patient who had a catheter related infection, and whose catheter broke during treatment.

for psychological reasons derived some benefit from this. Conversely, two older children objected strongly to the catheter, finding it a constant reminder of their illness, and the catheters were removed at their request.

\section{Discussion}

These results document a high incidence of infection by coagulase negative staphylococci, confirming reports from other oncology or haematology units. ${ }^{3-5}$ Shapiro et $a t^{\circ}$ reported 14 bacteraemic episodes in 174 patient months of catheter use ( $0 \cdot 27$ episodes per 100 days of catheter use) in a paediatric population, but coagulase negative staphylococci were identified in only three episodes. Hickman et al reported an overall incidence of septicaemia of $38 \%$, but the figure for coagulase negative staphylococcal infection was not given. Reed et al ${ }^{7}$ described a rate of 0.46 bacteraemias per 100 patient days using Hickman catheters in patients undergoing prolonged chemotherapy for leukaemia and other malignancies. Recently Sanz et al have reported bacteraemias in 23 of 34 patients, and over half were infected with coagulase negative streptococci. Only in this last report were catheters routinely placed before intensive inpatient chemotherapy was given. Shapiro et al seem to have used the catheters mainly on outpatients, while Hickman's use was exclusively in patients receiving bone marrow transplantation in a sterile environment and receiving prophylactic antibiotics.

The main difficulties in comparing results are the differences in the criteria that individual workers have used for insertion of the catheters and in the ways that they have expressed their results. Our results in outpatients show a very low infection rate, 
rising dramatically when the catheters are used for intensive inpatient treatment. Obviously the patients in hospital are the most immunosuppressed and ill in a general sense; however, the mix of patients and the timing of catheter insertion are likely to alter rates of infection even when the care given to the catheters is identical.

Another difficulty in interpretation is the definition of catheter related infection. Our criteria are those used by Shapiro et at $t^{t}$ but the definition includes the 'background' septicaemia without definable source of infection so often seen in the immunosuppressed. One way of investigating this problem is by quantitative blood cultures from both the central catheter and a peripheral vein. ${ }^{89}$ When the catheter is removed the tip may be cultured ${ }^{10}$ but it has been shown that conventional culture of the tip underestimates colonisation in some types of catheter. ${ }^{11}$ We do have a comparable group of children treated concurrently on the same protocols as part of an antibiotic trial; ${ }^{12}{ }^{13}$ in 17 bacteraemic episodes in children without indwelling central venous catheters coagulase negative staphylococci were isolated in only one patient. This suggests strongly that while some of the non-coagulase negative staphylococcal organisms may be unrelated to the catheter, the increased incidence of coagulase negative staphylococcal infection in our catheterised patients is directly related to the catheters. Other authors disagree ${ }^{14}$ and suggest that granulocytopenia predisposes to coagulase negative staphylococcal infection, but this is not supported by our findings. The propensity of coagulase negative staphylococci to colonise plastic surfaces and to resist the antibacterial activity of the blood has been reported by many workers. ${ }^{15-17}$

Nine episodes of bacteraemia yielded multiple (up to six) isolates, not only of different species but of different strains of the same species, whether coagulase negative staphylococci or other bacteria. The criteria used to separate the strains are not absolute, but together the results clearly indicate contemporaneous colonisation by multiple strains. Indeed the difficulty of first recognising variations within the growth on the culture plates, and the fact that this aspect was investigated retrospectively on isolates selected for laboratory preservation, suggest that we have underestimated the heterogeneity of the bacterial growth, and that very discriminating examination of cultures in these patients is essential.

The results presented show clearly that bacteraemia occurring in patients with indwelling central venous catheters can be eradicated in most -in this series $72 \%$. Obviously the risks of prolonged antibiotic treatment-possible emergence of resistant bacteria and fungal overgrowth-must be con- sidered as well as other as yet theoretical problems such as immune complex nephritis. There is little point in subjecting a child to these risks if the catheter has reached the end of its period of maximum use, hence decisions on removal must be made on an individual basis. We now regard mixed infection as a more difficult problem and consider removal earlier in these circumstances.

While we have emphasised the infections and other complications seen during our first three years' use of these catheters, the positive aspects are more difficult to quantify. The complications have, in most cases, been readily manageable and both doctors and patients would prefer not to go back to peripheral venepunctures. Our criteria for insertion of indwelling central venous catheters have not changed after analysis of these data, but we do not think that a wider use of these catheters is indicated. The risk of catheter related bacteraemia is high (16 of 36 patients) but eradication of infection is possible without removing the catheter. We suggest that careful appraisal of the benefits and risks in individual patients is mandatory if these catheters are to be used to optimal benefit in a paediatric oncology population.

We thank Dr T L Pitt, Central Public Health Laboratory, Colindale, for assistance with typing of isolates; $\mathrm{Mr} \mathrm{M}$ James for the insertion of all the catheters; and Dr P Charleton, Dr A Oakhill, and Dr M G Mott for help and advice. P J D was supported by a grant from the Leukaemia Research Fund.

\section{References}

${ }^{1}$ Broviac JW, Cole JJ, Scribner BH. A silicone rubber atrial catheter for prolonged parenteral nutrition. Surg Gynecol Obstet 1973;136:602-6.

2 Hickman RO, Buckner CD, Clift RA, Sanders JE, Stewart P, Thomas ED. A modified right atrial catheter for access to the venous system in marrow transplant recipients. Surg Gynecol Obstet 1979;148:871-5.

${ }^{3}$ Blacklock HA, Pillai MV, Hill RS, Matthews JRD, Clarke AG, Wade JF. Use of modified subcutaneous right-atrial catheter for venous access in leukaemic patients. Lancet 1980;i:993-4.

${ }^{4}$ Sitges-Serra A, Puig P, Jaurrieta E, Garau J, Alastrue A, Sitges-Creus A. Catheter sepsis due to Staphylococcus epidermidis during parenteral nutrition. Surg Gynecol Obstet 1980; 151:481-3.

5 Sanz MA, Such M, Rafecas FJ, Martin G, Santos M. Staphylococcus epidermidis infections in acute myeloblastic leukaemia patients fitted with Hickman catheters. Lancet 1983;ii:1191-2.

6 Shapiro ED, Wald GR, Nelson KA, Spiegelman KN. Broviac catheter-related bacteremia in oncology patients. Am J Dis Child 1982;136:679-81.

${ }^{7}$ Reed WP, Newman KA, de Jongh C, et al. Prolonged venous access for chemotherapy by means of the Hickman catheter. Cancer 1983;52:185-92.

${ }^{8}$ Wing EJ, Norden CW, Shadduck RK, Winkelstein A. Use of quantitative bacteriologic techniques to diagnose catheterrelated sepsis. Arch Intern Med 1979;139:482-3.

9 Raucher HS, Hyatt AC, Barzilai A, et al. Quantitative blood cultures in the evaluation of septicaemia in children with Broviac catheters. J Pediatr 1984;104:29-33. 


\section{Darbyshire, Weightman, and Speller}

1" Maki DG, Weise CE, Sarafin HW. A semiquantitative culture method for identifying intravenous-catheter-related infection. $N$ Engl J Med 1977;296:1305-9.

$"$ Cheesbrough JS, Elliott TSJ, Finch RJ. A morphological study of bacterial colonisation of intravenous cannulae. J Med Microbiol 1985; (in press).

12 Darbyshire PJ, Williamson PJ, Pedler SJ, Speller DCE, Mott MG, Oakhill A. Ceftazidime in the treatment of febrile immunosuppressed children. J Antimicrob Chemother 1983;12 Suppl A:357-60.

13 Williamson PJ, Darbyshire PJ, Mott MG, Oakhill A, Speller DCE. Ceftazidime and tobramycin in the treatment of febrile immunosuppressed children. J Antimicrob Chemother 1984;14:671

14 Wade JC, Schimpff SC, Newman KA, Wiernik PH. Staphylococcus epidermidis: an increasing cause of infection in patients with granulocytopenia. Ann Intern Med 1982:97:503-8.
15 Peters G, Locci R, Pulverer G. Adherence and growth of coagulase-negative staphylococci on surfaces of intravenous catheters. J Infect Dis 1982;146:479-82.

${ }^{16}$ Franson TR, Sheth NK, Rose HD, Sohnle PG. Quantitative adherence in vitro of coagulase-negative staphylococci in intravenous catheters: inhibition with D-mannosamine. J Infect Dis 1984;149:116.

${ }^{17}$ Gray ED, Peters G, Verstegen M, Regelman WE. Effect of extracellular slime substance from Staphylococcus epidermidis on the human cellular immune response. Lancet 1984;i:365-7.

Correspondence (no reprints available) to Dr N C Weightman, Department of Microbiology, Bristol Royal Infirmary, Bristol BS2 $8 \mathrm{HW}$.

Received 2 November 1984 